\title{
A Study on the Distinction Between Extrovert vs Introvert in Learning English
}

\author{
Fitri Mauliddiyah Hayati \\ IAIN Pekalongan \\ fitrihayati801@gmail.com
}

\begin{abstract}
This paper aims to examine the differences abilities between extrovert and introvert personality in learning English. This study describes the differences in the ability of speaking, writing, listening and reading. The approach used in this study is a qualitative approach. Data were obtained by conducting observations and interviews with research subjects. The subjects of this study were students of the third semester of English Education at IAIN Pekalongan. The analysis in this study uses a descriptive analysis related to the differences in English skills in extroverts and introverts. The results showed that the differences between extroverted and introverted personalities on the ability to learn English. In speaking skills, extroverted students are more mastery than introverted students. While writing, listening, and reading skills introverted students are more mastered. But in the aspect of pronunciation \& accent, extroverts' vocabulary and fluency are superior than introverts. Introverts good in grammar, and comprehension. On the other hand, introverts have superior writing skills in terms of vocabulary, content, and expression. whereas extroverts only excel in terms of content and expression. The spelling and grammar is not influenced by the personality.Therefore each personality have own skills or advantages and disadvantages.
\end{abstract}

Key words: $\quad$ ekstrovert \& introvert, speaking, writing, listening, reading

\section{A. INTRODUCTION}

Carl Gustav Jung (1875-1961) called the type of human personality is introvert and extrovert. Jung said that extroverts are personalities who are more influenced by the objective world. Thoughts, feelings, and actions are more determined by the environment. The behavior of extrovert is described as open, cheerful, likes to 
get along with others, tends to interact with others and not sensitive. While introvert individuals are individuals who tend to withdraw from social contact. Their interest and attention is more focused on his own thoughts and feelings. Jung describes introvert behavior as quiet people, distancing themselves from social contact, not happy to be in a crowd (Haryanto and Nur 2017). Personality types (extrovert \& introvert) and learning English are two interrelated things (Husain and Ibrahim 2019). They have different style in learning english, such as in reading, writing, listening, and speaking. They are also have different skills in three language elements such as pronunciation, vocabulary, and grammar (Diana 2018).

However, learning English have some difficulties for students(Susanthi 2021) . Some of the difficulties experienced by students such as difficulty speaking according to pronunciation, writing according to structural rules (grammatical), and difficulties in listening and reading English. Most students have difficulty translating the information they receive into Indonesian, and their dependency on dictionaries is still quite high (Angeline, Biomedical, and Departement 2020).

Some of these difficulties are related to personality factors. Because personality is one of the internal factors that affect students' abilities in learning English (Shehni and Khezrab 2020). Personality is included in the psychological internal factors that act as an important predictor of cognitive performance as well as influence academic success. Extrovert and introvert personalities have different characters, therefore they have different learning processes and outcomes (Noprianto 2018).

The process of language learning is related to the sensitivity of each personality to its character or behavior. In this case, they are extrovert versus introvert, sensing versus perception, thinking versus feeling, judging versus understanding, ambiguity tolerance versus ambiguity intolerance, and left brain versus right 
brain. Like their typical character, extroverts are more interested in interacting with other people. Therefore, extroverts prefer to study in groups and solve problems together. In contrast, introverts prefer to study individually. Introverts like to learn independently and more often use the five senses and observe facts or events to understand and solve a problem (Razawi n.d.).

In learning English, several studies have shown that introverts good at some skills. Introvert personality type with reading comprehension has a significant correlation. The more introverted students, the better their reading comprehension (Husain and Ibrahim 2019). Previous research also said that there are differences in the ability to write English essays between introverts and extroverts. The introvert personality type has higher writing skills than the extroverted personality type (Sutrisno, Rasyid, and Rahmat 2018). However, another study (Samand, Sailan, and Lio 2019) said that extrovert students had better performance in speaking skills than extrovert students. Similar to other skills, listening skills also have differences in English listening scores between introvert and extrovert students. Introvert students have better listening scores than extrovert students (Travolta, Mulyadi, and Imranuddin 2018).

Various studies conducted previously have analyzed the overall ability of extrovert and introvert in learning English. The research of Samand, Husain \& Ibrahim, and Travolta discusses the ability of introvert and extrovert from four skills, such as speaking, Writing, Listening, Reading. However, somewhat different from the research, this study will look at the ability of introverts and extroverts as a whole. Discuss from the four aspects of skills, reading, writing, listening and speaking. And in terms of three language elements such as pronunciation (pronunciation), vocabulary (vocabulary), and grammar (language structure). Because in the four main English skills there are several supporting 
factors. So in this study, it will be studied how the ability of extroverts and introverts on these supporting factors. So it can be concluded that the extrovert or introvert has the ability to one or more of the four basic English skills. Then the research concluded in outline how the ability of extroverts and introverts in learning English.

\section{B. RESEARCH METHOD}

This research use desciptive qualitative approach. The subjects of this study were students of the third semester of English at IAIN Pekalongan. There are two instruments used in this study, there are observation and interview. Observations were made to observe the character and actions of students during English language learning. How each student acts and his English skills.

Furthermore, interview to obtain information about the personality of students. Some questions related to extrovert and introvert personality indicators were presented. Then the research subjects were asked to answer these questions and explain the reasons. In the interview the research subjects were also asked about their ability to speak English. The results of the interviews were then matched with previous literature regarding the ability of extroverts and introverts in learning English. The results of the interviews were also matched with the results of observations. Then the data were analyzed and described from the two instruments.

\section{FINDINGS AND DISCUSSION}

\section{Findings}

\section{Impact Personality in Foreign Language Learning}

Introvert and extrovert students have different characters from each other. This character makes them both have different abilities. For example, extrovert 
students show higher academic achievement when studying with a friend. They also like learning activities that have tangible results and involve communicating with others. They really stand out when speaking in class. While introvert students can learn more perfectly in a quiet state. Regarding classroom activities, introvert types prefer reading, writing, listening to lecturers' lectures, and research in verbal work. They also tend to be independent and prefer to work alone. Introvert students are almost uncomfortable if they have to discuss in groups. They also hesitate to speak in front of the class.

\section{Speaking}

Students' speaking ability is seen from their fluent in English. Through interview, students were asked to answer questions in English. Through this interview, students are assessed based on five aspects of speaking, namely pronunciation \& accent (pronunciation \& accent), grammar (grammar), vocabulary (vocabulary), fluency (fluency), and comprehension (understanding). The results showed that extroverts had better English speaking skills than introverts.

The following table shows the percentage of speaking test scores for extroverted and introverted students.

Table 1. Results of the Percentage of Speaking Ability of Extrovert Students

\begin{tabular}{|c|c|c|}
\hline $\begin{array}{c}\text { Speaking } \\
\text { Ability }\end{array}$ & $\begin{array}{c}\text { Percentage of } \\
\text { Extrovert }\end{array}$ & $\begin{array}{c}\text { Ability } \\
\text { Level }\end{array}$ \\
\hline Pronun \& accent & $23,00 \%$ & High \\
\hline Grammar & $16,00 \%$ & Low \\
\hline Vocabulary & $20,50 \%$ & High \\
\hline Fluency & $21,80 \%$ & High \\
\hline Comprehension & $17,70 \%$ & Low \\
\hline
\end{tabular}


Table 2. Results of the Percentage of Speaking Ability of Introverted Students

\begin{tabular}{|c|c|c|}
\hline $\begin{array}{c}\text { Speaking } \\
\text { Ability }\end{array}$ & $\begin{array}{c}\text { Percentage of } \\
\text { Introvert }\end{array}$ & $\begin{array}{c}\text { Ability } \\
\text { Level }\end{array}$ \\
\hline Pronun \& accent & $16,85 \%$ & Low \\
\hline Grammar & $23,15 \%$ & High \\
\hline Vocabulary & $18,75 \%$ & Low \\
\hline Fluency & $18,10 \%$ & Low \\
\hline Comprehension & $23,15 \%$ & High \\
\hline
\end{tabular}

Based on the data in the table above, it is clear that there are differences in the speaking ability between introvert and extrovert students. The results show that $66.3 \%$ of extrovert students have the ability to speak English in the aspects of pronunciation \& accent (pronunciation \& accent), vocabulary (vocabulary), fluency (fluency). While the aspects of grammar (grammar) and comprehension (understanding) only have a percentage of $33.7 \%$. Meanwhile, introvert students have a percentage of $46 \%$ in aspects of grammar (grammar) and comprehension (understanding). Meanwhile, in the aspect of pronunciation \& accent, vocabulary (vocabulary), fluency (fluency) has a percentage of $53.7 \%$.

\section{Writing}

To determine students' writing skills, observations were made on students' writing assignments. In this study, students observed essay assignments. The assessment focuses on five basic aspects of writing, namely vocabulary, speech, grammar, content, and expression.

Table 3. Results of the Percentage of Writing Ability of Extrovert Students

\begin{tabular}{|c|c|c|}
\hline $\begin{array}{c}\text { Writing } \\
\text { Ability }\end{array}$ & $\begin{array}{c}\text { Percentage of } \\
\text { Ekstrovert }\end{array}$ & $\begin{array}{c}\text { Level } \\
\text { Ability }\end{array}$ \\
\hline Vocabulary & $15,55 \%$ & Low \\
\hline
\end{tabular}


English Education: Jurnal Tadris Bahasa Inggris pISSN 2086-6003 | eISSN 2580-1449

Vol 14 (2), 2021, 352-365

\begin{tabular}{|c|c|c|}
\hline Spelling & $18,80 \%$ & Low \\
\hline Grammar & $15,60 \%$ & Low \\
\hline Content & $25,00 \%$ & High \\
\hline Expression & $25,05 \%$ & High \\
\hline
\end{tabular}

Table 4. Results of the Percentage of Writing Ability of Introvert Students

\begin{tabular}{|c|c|c|}
\hline $\begin{array}{c}\text { Writing } \\
\text { Ability }\end{array}$ & $\begin{array}{c}\text { Percentage of } \\
\text { Extrovert }\end{array}$ & $\begin{array}{c}\text { Ability } \\
\text { Level }\end{array}$ \\
\hline Vocabulary & $20,20 \%$ & High \\
\hline Spelling & $18,80 \%$ & Low \\
\hline Grammar & $15,50 \%$ & Low \\
\hline Content & $25,00 \%$ & High \\
\hline Expression & $25,05 \%$ & High \\
\hline
\end{tabular}

Based on the data above, extroverted students have advantages in aspects of content $(25.00 \%)$ and expression (25.05\%). Meanwhile, they were low in vocabulary $(15.55 \%)$, spelling $(18.80 \%)$, and grammar $(15.60 \%)$. Meanwhile, introverted students are low in the grammar aspect (15.60\%). However, they excel in vocabulary $(20.20 \%)$, spelling $(18.80 \%)$, content $(25.00 \%)$, and expression $(20.50 \%)$.

\section{Reading}

In this study, the research subjects were asked to read the narrative text. After that they have to answer some questions related to their understanding with the text.

Table 5. Reading comprehension scores of Introvert and Extrovert Students

\begin{tabular}{|r|l|}
\hline No & Question \\
\hline 1 & Understand the outline of the story \\
\hline 2 & Explain the characters in the story \\
\hline 3 & Explain the background of the story \\
\hline 4 & Explain the problems faced by the \\
\hline
\end{tabular}




\begin{tabular}{|c|l|}
\hline 5 & characters \\
\hline 5 & $\begin{array}{l}\text { Explain the problem solving until } \\
\text { the end of the story }\end{array}$ \\
\hline
\end{tabular}

Based on the table above, introverted students have a better understanding of the text than extrovert students. Based on the table above, introvert students can almost answer all the questions correctly. However, extrovert students cannot answer all the questions correctly. So, it can be concluded that introvert have better reading comprehension than extrovert students. Introverts are superior to extroverts because introverts are known to be more thorough and careful. Based on interviews, the majority of introvert students like reading activities. When they read they are fully concentrated. They read every word very carefully. Introvert students almost understand the content of the story in general. They also master the detailed questions in the text.

On the other hand, extroverted students lack reading skills. Extroverted students in the reading test only mastered two of the five question points. They are able to explain the general outline of the story and the setting of the story. However, for more detailed questions in the story they are less familiar with it.

\section{Listening}

To determine listening comprehension skills, students are asked to listen to short conversations in English. Students listen to 3 audio listening. Then students have to answer some questions and retell what the contents of the conversation are in Indonesian. Audio listening is played once. In listening ability, there is a significant difference between introverted and extroverted personalities. Introverted students have better listening comprehension skills than extroverted students. 


\section{Discussion}

Extroverted students have better ability in speaking English than introvert. This happens because the extrovert personality is known to be active in speaking and confident. So their pronunciation $\&$ accent is good because they speak in a style like native speakers. They love being the center of attention. They want to show that they master English. So they imitate the pronunciation of native speakers. However, not all extrovert are good in their pronunciation. Some extrovert students have poor pronunciation, but they are very confident when speaking. Extroverted students are very active. They speak English without hesitation even though the meaning and pronunciation do not match.

On the other hand, Extrovert pay less attention to the grammatical structure of the spoken sentence. They are personality that acts spontaneously. Don't think much when doing something. As a result, their grammatical and comprehension aspects are lacking. Because in this aspect requires precision and high enough thinking. So, even though extrovert students seem fluent in speaking, their grammatical skills are actually a bit poor. They are also low in the aspect of understanding English.

While introvert students are known to be more quiet than extroverted students. Introvert students lack confidence when it comes to speaking in English. This is influenced by several factors, such as fear of being mispronounced (pronunciation), doubting the suitability of meaning (meaning), and being embarrassed because they rarely speak English.

Introvert students prefer to study than practice. So that they are more prominent in the aspects of grammar and comprehension. Introverts are good learners in the classroom. They like to understand something and tend to be careful in doing 
something. So that they excel in the aspects of grammar and comprehension which require a high level of precision and thinking.

Based on the data, Introverted students tend to be passive when speaking. However, they are active in understanding word structure and sentence comprehension. The results of the interview show the reasons why introverted students are lacking in speaking. The reason is because introvert students rarely practice speaking in English so they do not master this skill. They are lacking in aspects of pronunciation $\&$ accent, grammar, and fluency. These three aspects are required to require a lot of practice.

On writing skills, extroverts good in content and expression. This happens because extroverted students are known to be expressive in expressing their feelings. They also have lots of ideas for finding interesting and creative content. However in terms of vocabulary, spelling, and grammar, they lack mastery. Extroverts tend to be less conscientious when it comes to things. Extrovert are spontaneous individuals and don't think much about doing things. Extrovert personality likes challenges, dares to take risks but gets bored quickly. That's the reason why extrovert don't really stand out when it comes to writing.

Introvert students are better at writing than extroverts. This is because the basic character of an introvert who likes to learn and explore things. they tend to be thorough and careful in doing things.

However, in terms of grammar, both are equally low. So it can be concluded that introvert-extrovert personality affects students' writing skills, except for the grammar aspect.

Introvert students have a better understanding of the text than extrovert students. Based on the table above, introverted students can almost answer all the questions 
correctly. However, extrovert students cannot answer all the questions correctly. So, it can be concluded that introverts have better reading comprehension than extrovert students. Introvert are superior to extrovert because introvert are known to be more thorough and careful. Based on interviews, the majority of introverted students like reading activities. When they read they are fully concentrated. They read every word very carefully. Introvert students almost understand the content of the story in general. They also master the detailed questions in the text.

On the other hand, extrovert students have lack reading skills. Extrovert students in the reading test only mastered two of the five question points. They are able to explain the general outline of the story and the setting of the story. However, for more detailed questions in the story they are less familiar with it.

The basic difference is seen in the reading ability between introvert and extrovert students. These differences occur due to differences in the character of each personality. An introverted personality with a calm character, likes to learn and explore things. in contrast to introvert, extrovert are cheerful, talkative, and easily bored in doing things. Extrovert personalities also do not like activities that require high concentration and accuracy. However, extrovert students can read for a long time. During interviews, they revealed that they could read and understand a passage if they were interested in it. Extrovert prefer reading such as short stories, articles about life style or traveling. They do not like reading such as novels, scientific works, and news.

In listening ability, there is a significant difference between introvert and extrovert personalities. Introvert students have better listening comprehension skills than extrovert students. This happens for several reasons. The first reason, because of the differences in characteristics between introvert and extrovert. Introvert prefer to listen than talk. they tend to concentrate easily and are very detailed on things. 
Meanwhile, extrovert students do not like to do detailed activities and require high concentration. They tend to be impatient and get bored easily. Extrovert prefer to talk than they have to listen. So that listening does not match the extrovert personality. Listening is a skill that requires concentration, patience, and accuracy to perceive and interpret the information obtained. When answering and listening to the listening test, students are required to focus for a long time. That is the reason why extroverted students score less than introvert students.

The second reason, the way they express their feelings or emotions. Introvert students prefer to work alone rather than work in groups. they like solitude and serenity. They enjoy doing things on their own, such as reading books, writing, and listening to music. On the other hand, extroverted students are very good at working with other people. They are active during group discussions. They like crowds and interact with many people. So that extroverted students feel pressured and very bored when they have to listen to the listening test and answer questions.

\section{CONCLUSION AND SUGGESTION}

\section{Conclusion}

There is a significant relationship between personality and students' ability to learn English. As in speaking skills, extrovert students are more mastery than introvert students. While in writing, listening, and reading skills, introverted students are more mastered.

However, in some aspects, both have their own advantages and disadvantages. For example, extroverts excel in pronunciation \& accent, vocabulary and fluency when speaking. While introvert are weak in this regard. Introvert excel in terms of grammar, and comprehension when speaking in English. On the other hand, introverts are better at writing than extrovert. Introvert excel in terms of vocabulary, content, and expression. while extrovert only excel in terms of 
content and expression. In this case spelling and grammar skills are not influenced by personality. In relation to reading and listening skills, introvert dominate more than extrovert. Introvert excel in comprehension in both reading and listening. However, extroverts are lacking in this regard.

This research supports the previous research conducted by Sutrisno. Introverts are better at writing than extroverts. This study also strengthens previous research conducted by Husain \& Ibrahim and Travolta. That introvert personality has more ability in terms of reading and listening. However, this study is different from the research conducted by Samand. Samand's research says that introverts are better at speaking than extroverts.

\section{Suggestion}

Furthermore, in order to fully investigate the relationship between student personality and English language learning ability, it is necessary to conduct a more comprehensive study with a larger and different number of individuals. Different research approaches are also needed. By using different demographic groups, researchers can also examine the possible relationship between personality and English learning ability among students with different majors. Further studies can utilize more resources to provide a broader picture of the influence of personality on English learning ability.

\section{E. REFERENCES}

Angeline, Felicia, Biomedical, and Engineering Departement. 2020. The Number One Language, English: The Aspects of Learning English and Its Difficulties.

Diana, Laksmi. 2018. "HAMBATAN PEMBELAJARAN BAHASA INGGRIS MAHASISWA FAKULTAS PERTANIAN UNIVERSITAS PEMBANGUNAN NASIONAL VETERAN JAWA TIMUR." Berkala Ilmiah AGRIDEVINA 7(1):93-101. doi: 10.33005/adv.v7i1.1133. 
Haryanto, Dadang, and Ilham Muhamad Nur. 2017. "SISTEM PAKAR TES KEPRIBADIAN EKSTROVERT DAN INTROVERT DENGAN METODE FORWARD CHAINING." JUTEKIN (Jurnal Teknik Informatika) 5(2). doi: 10.51530/jutekin.v5i2.138.

Husain, Balqis, and Ibrahim Ibrahim. 2019. "Perbedaan Prestasi Belajar Bahasa Inggris Siswa Ditinjau Dari Tipe Kepribadian Introvert Dan Extrovert." Qalam : Jurnal Ilmu Kependidikan 7(2):91-106. doi: 10.33506/jq.v7i2.371.

Noprianto, Eko. 2018. "Extrovert versus Introvert Students: What EFL Learning Strategy Do They Use?” ASIAN TEFL 2:119-35. doi: 10.21462/asiantefl.v2i2.34. Razawi, Nurul Amilin. n.d. "STUDENTS' DIVERSE LEARNING STYLES IN LEARNING ENGLISH AS A SECOND LANGUAGE.” 2(19):8.

Samand, Sri Muniarty, Zalili Sailan, and Asrun Lio. 2019. "Analysis On The Relationship Of Extrovert-Introvert Personality And Students' Speaking Performance In English Study Program Of Halu Oleo University." Journal of Language Education and Educational Technology (JLEET) 4(1). doi: 10.33772/jleet.v4i1.6677.

Shehni, Maryam Cheraghi, and Tahereh Khezrab. 2020. "Review of Literature on Learners' Personality in Language Learning: Focusing on Extrovert and Introvert Learners." Theory and Practice in Language Studies 10(11):1478-83. doi: 10.17507/tpls.1011.20.

Susanthi, I. Gusti Ayu Agung Dian. 2021. "Kendala Dalam Belajar Bahasa Inggris Dan Cara Mengatasinya." Linguistic Community Services Journal 1(2):64-70. doi: 10.22225/licosjournal.v1i2.2658.

Sutrisno, Bejo, Yumna Rasyid, and Aceng Rahmat. 2018. "THE EFFECT OF COOPERATIVE LANGUAGE LEARNING AND PERSONALITY TYPES TOWARDS ESSAY WRITING." English Review: Journal of English Education 6(2):95-104. doi: 10.25134/erjee.v6i2.1259.

Travolta, Yessi, Mulyadi, and Imranuddin. 2018. “A COMPARATIVE STUDY ON INTROVERT AND EXTROVERT STUDENTS PERSONALITY IN ENGLISH LISTENING SCORES." Journal of English Education and Teaching 2(2):9-19. doi: 10.33369/jeet.2.2.9-19. 